\title{
COMMUNITY EMPOWERMENT IN WASTE MANAGEMENT HOUSEHOLD AT RW 03 KELURAHAN KALISARI KECAMATAN PASAR REBO JAKARTA TIMUR
}

\author{
Uuh SUKAESIH ${ }^{*}$, Miswan MISWAN \\ Faculty of Economics and Business, Sahid University, Indonesia \\ *sukaesihuuh@gmail.com
}

\begin{abstract}
More than 90 percent of the community in RW 03 Kalisari Kelurahan Pasar Rebo District do not separate wet and dry waste. The purpose of community service is to change this behavior in RT 05.07 and 10 RW 03 Kalisari Village in disposing of garbage, namely separating dry waste from wet garbage so that waste is disposed of in a landfill (TPA) is reduced. The method used is to provide counseling, guidance, and also simulations to residents so that they are willing to separate wet and dry waste so the amount of waste disposed in landfills is reduced. The knowledge of residents in RT 05, RT 07, and RT 10 RW 03, Kalisari Village, Pasar Rebo District, East Jakarta, has increased on how to manage household waste. The behavior of residents in RT 05, RT 07, and RT 10 RW 03, Kalisari Village, Pasar Rebo Subdistrict, East Jakarta, is getting better at managing household waste, from the results of research, about 30 percent of the existing residents have separated dry waste from wet waste. Counseling and guidance activities in household waste management need to be carried out regularly and continuously so that the number of people or households that separate wet waste from dry waste continues to grow.
\end{abstract}

Keywords: Community empowerment, Waste management.

\section{BACKGROUND}

Garbage has always been a serious problem, especially in big cities, and one of the many cities is DKI Jakarta. DKI Jakarta is the capital city of Indonesia with a large population and continues to increase year to year. According to Adipura 2015-2016 data from the Ministry of Environment and Forestry, it was found that the composition of plastic waste in 2013 was 14 percent, to 16 percent in 2016. For organic waste, the period decreased from 60 percent to 57 percent (Ismail Yunita, 2019).

One of the temporary waste disposal sites, located in RT 07 RW 03, Kalisari Village, Pasar Rebo Subdistrict, East Jakarta, is a temporary shelter for residents in $3 \mathrm{RT}$, that includes RT 05, RT 07, and RT 10, RW 03, Kalisari Village. The garbage is transported by using a garbage truck twice a week, every Tuesday and Saturday. People can store their waste in that place from 6.00 to 8.00 on the schedule where the waste will be transported. According to information from the garbage collector, the average amount of waste from the 3 RTs is 2.5 tons per one transport or an average of 5 tons per week or 20 tons per month.

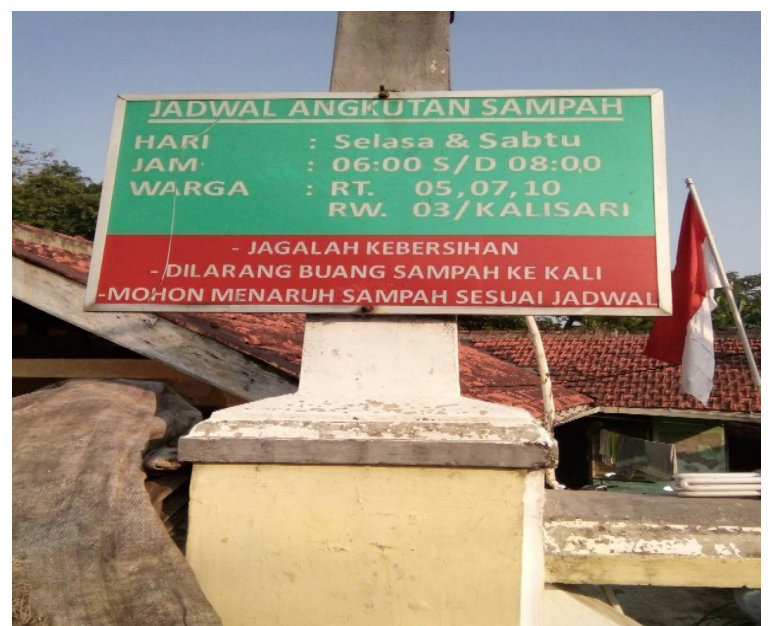

Picture 1. Waste Transport Schedule in RT 05, 07, 10 RW 03 Kalisari Village
Most of the community members in RW 03 Kalisari Village, Pasar Rebo District, East Jakarta, which is more than 90 percent, do not separate wet waste from the dry waste or those that can be recylcled, so that the waste is mixed. Even if residents or the community participate in dealing with the waste problem, the amount of waste transported and disposed of in landfills will be reduced. Participation is one way to realize community empowerment. People can participate individually or collectively in an activity but that participation will not necessarily give them more control over their lives (D Septianti, 2020). Therefore, it is necessary to provide counseling and guidance regarding "Community Empowerment in Household Waste Management" in RT 05, RT 07, and RT 10 RW 03, Kalisari Village, Pasar Rebo District, East Jakarta.

The purpose of community empowerment in managing household waste in RT 05, 07 and 10 RW 03, Kalisari Village, Pasar Rebo Subdistrict, is to provide counseling or providing information and also guidance to the community in RT 05,07 and 10 RW 03 Kalisari Village, Pasar Rebo District regarding The importance to separate household waste between dry waste will be used by scavengers and wet waste to be disposed of in the Final Disposal Site.

\section{METHODS}

The method used in the "Community Empowerment in Household Waste Management" activity is by counseling, giving guidance and simulation to residents who live in RT 05, 07 and 10 RW 03, Kalisari Village, Pasar Rebo District, East Jakarta.

Counseling is carried out during the women's social gathering which is carried out on the first Sunday and Saturday of the second week in October 2019 until February 2020. However, from March 2020 to March 2021 due to the Corona outbreak, social gathering events or gatherings attended by many residents are not allowed 
again. Activities were also carried out by placing banners in several strategic places in the form of invitations and information to always separate waste between dry waste and wet waste.

Guidance is done by providing knowledge, and understanding individually to be more aware and willing to carry out activities to sort wet waste or organic waste from dry or inorganic waste that can still be used or can be recycled again.

The simulation is then carried out by giving examples and demonstrating how to sort and pack dry waste such as cardboard waste, plastic waste used for drinking water to make it more concise when temporarily stored at home before the waste is given to scavengers or collected in temporary landfills.

\section{RESULTS AND DISCUSSION}

Waste management activities in the community environment (RW 03) Kalisari Village are moved by involving the community. Namely, the community as a waste producer is required to sort or separate wet waste from dry waste that can still be recycled or resold. According to Nugraha (2018) the pattern of waste management by involving the community as those who can play an active role in reducing the volume of waste is the right decision in anticipating the increase in the volume of urban waste which continues to increase due to the increase in population.

The community of RW 03 Kalisari Sub-district has participated in direct waste management (collecting, storing, separating dry and wet waste) as well as delivering it to the temporary shelter 2 times a week, every Tuesday and Saturday between 5.00 and 7.30. in the morning and then transported by garbage trucks to the Bantar Gebang Final Disposal Site (TPA). Indirect participation of the community of RW 03 Kalisari Village in waste management is by participating in paying waste fees of Rp. 10000 per family head which is used for additional money for waste officers. According to Yuliastuti, et al (2013), community participation in waste management is indirect, namely community involvement in financial problems by paying a retribution for waste services. One form of participation in waste management is willingness to pay for improving waste management facilities so that environmental cleanliness and quality are maintained.

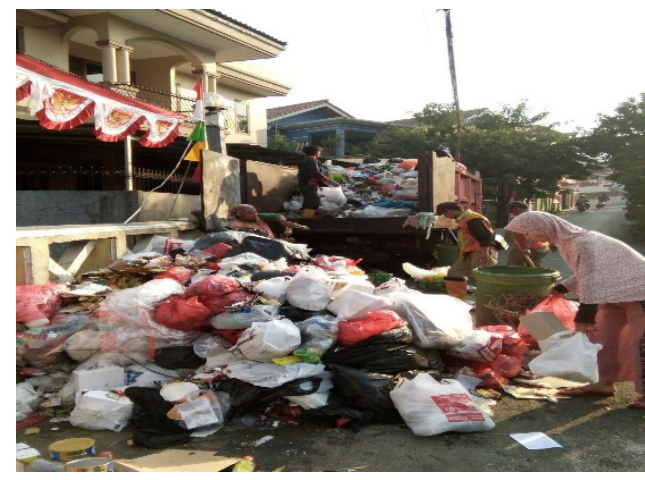

Picture 2. The Habits of Residents Before Counseling is done, namely not Separating Dry Waste from Wet Waste
Activities that are used in waste management are counseling. As a practical action, counseling is an effort made to encourage behavior change in individuals, groups, communities. This is done so that communities want to change for the better and are able to solve the problems that they face. The purpose of counseling is nothing but a quality and dignified human life and life (Amanah, 2013).

Counseling provides information about the amount of household waste that is very large and if it is not managed properly, for example not separating wet waste from dry waste, the amount of waste will keep increasing, in addition to separating wet waste from dry waste, residents are also encouraged to reducing the use of plastic such as reducing the use of plastic bags, plastic cups, plastic bottles or packaged drinks. Even if you use it, it is recommended that the waste be separated from waste that cannot be used. Counseling was carried out to women in several RTs in the RW 03 Kalisari Village, Pasar Rebo District, East Jakarta from November 2019 to February 2020. Activities are also supported by placing banners in several strategic places in the form of invitations and information to always carry out waste separation between dry waste and wet waste. The purpose of installing the banner is to provide information to all residents to always separate waste between dry waste that can still be used and wet waste. By separating dry waste from wet waste, the amount of waste that is disposed of to the final disposal site will decrease and the waste that can still be sold or reused will increase.

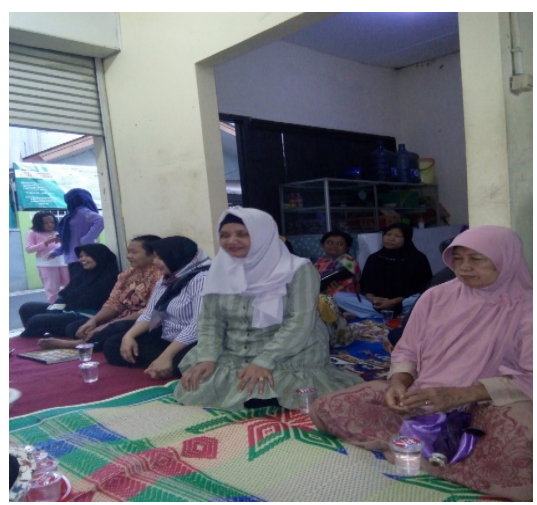

Picture 3. Counseling Activities Conducted to Mothers during the Arisan Event

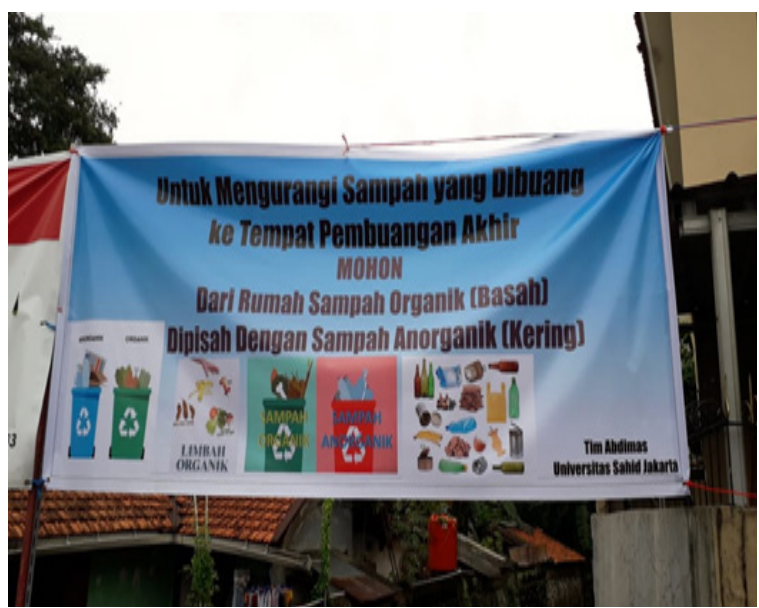

Picture 4. Banners installed in several strategic places 


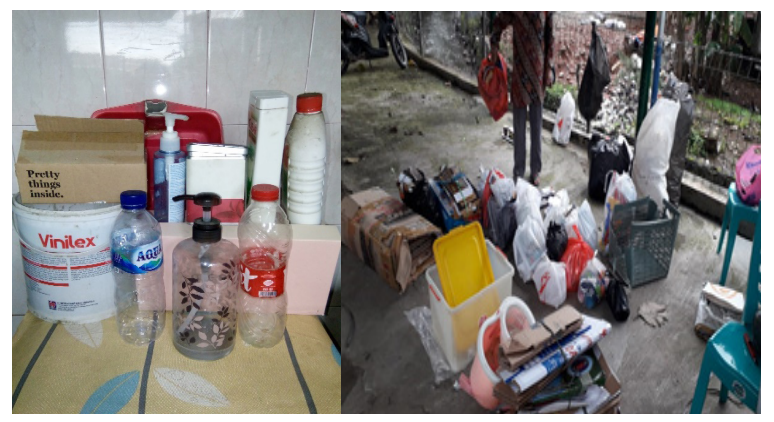

Picture 5. People Separate Dry Waste from Wet Waste

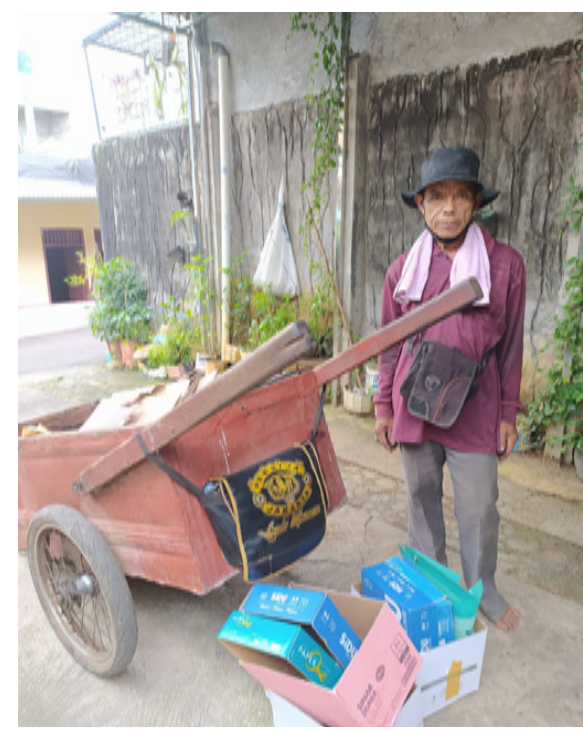

Picture 6. Dry Garbage Collected Then Given to Junkman or Garbage Scavengers

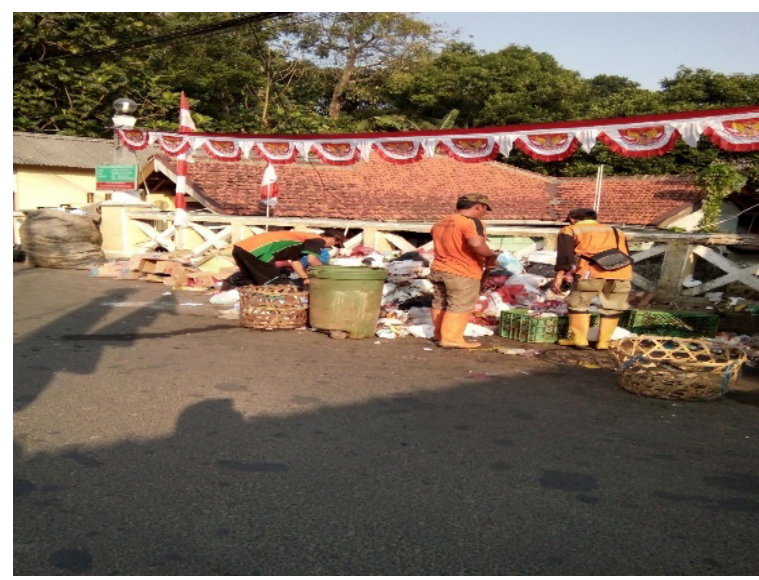

Picture 7. Garbage Officers Separate Dry Waste from Wet Waste

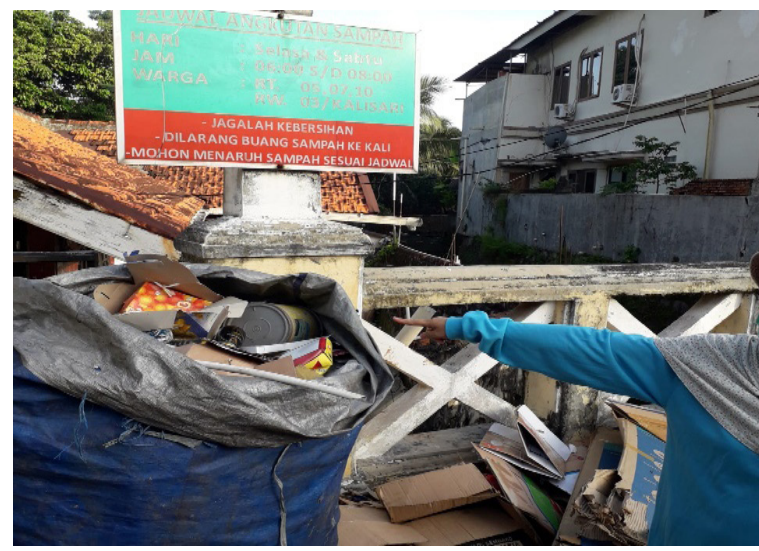

Picture 8. Dry Waste Separated from Wet Waste

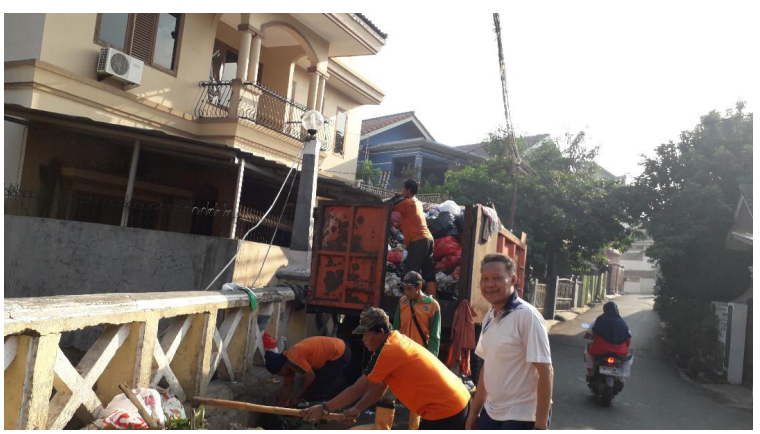

Picture 9. Wet Waste Ready to be Transported to Final Disposal

Community service activities regarding Community Empowerment in Household Waste Management at RT 05, RT 07, and RT 10 RW 03 Kalisari Village, Pasar Rebo District, East Jakarta, which took place from October 2019 to March 2021 carried out by a team from the University has been going well and was greeted with high enthusiasm by the community, this was marked by every outreach, many participants were present and actively asked if there were things that were deemed unclear, participants also added materials that support efforts to reduce the amount of waste produced by residents and always separated wet waste with dry waste that can still be recycled.

By holding counseling, guidance and simulations on household waste management, knowledge and public awareness will increase as well as people's behavior in managing household waste for the better, this is based on research, by asking 30 residents it turns out that 9 residents have separated dry waste by wet waste, meaning that the number of residents who separate dry waste from wet waste is $30 \%$. In addition, the amount of dry waste that has been collected in temporary landfills is higher than before the activity. Thus the wet waste that is disposed of in landfills is reduced and the waste that can be used or recycled is increased.

\section{CONCLUSIONS AND SUGGESTIONS}

Conclusions and suggestions from this activity are: The knowledge of residents in RT 05, RT 07, and RT 10 RW 03, Kalisari Village, Pasar Rebo District, East Jakarta, has increased on how to manage household waste. The behavior of residents in RT 05, RT 07, and RT 10 RW 03, Kalisari Village, Pasar Rebo Subdistrict, East Jakarta, is getting better at managing household waste, from the results of research, about 30 percent of the existing residents have separated dry waste from wet waste.

Counseling and guidance activities in household waste management need to be carried out regularly and continuously so that the number of people or households that separate wet waste from dry waste continues to grow.

\section{ACKNOWLEDGEMENT}

This community service activity is a grant and funded by the Institute for Research and Community Service (LPPM) at Sahid University. 


\section{REFERENCES}

Amanah, Siti. (2013). Makna Penyuluhan dan Transformasi Perilaku Manusia. Jurnal Penyuluhan, 1 (3), $63-67$.

Ismail,Yunita. (2019). Community Empowerment in Household Waste Management. Journal of Community Engagement, 01 (01), 24 - 29.

Nugraha, Aditya. (2018). Persepsi dan Partisipasi Masyarakat terhadap Pengelolaan Sampah Rumah Tangga melalui Bank Sampah di Jakarta Selatan. Jurnal Pengelolaan Sumberdaya Alam dan Lingkungan, 1 (8), 7 - 14.
Penebar Swadaya. (2014). Penanganan dan Pengolahan Sampah. Jakarta: Penebar Swadaya.

SeptantiD, etal.(2020). Environmental and WasteManagement Based on Community Empowerment in Surabaya. IOP Comference Series : Earth and Environmental Science.

Soliati, Suzi. (2019). Community Empowerment in Managing Waste Through Takakura Training. Jurnal Empowerment, 8 (1), 48 - 54.

Yuliastuti, et al. (2013). Partisipasi Masyarakat dalam Pengelolaan Sampah di Kabupaten Bandung. Jurnal Ekonomi dan Bisnis Universitas Udayana, 2 (6), $374-393$. 